\section{NOTICE}

This report was prepared as an account of work sponsored by the United States Government. Neither the United States nor the United States Atomic Energy Commission, nor any of their employees, nor any of their contractors, subcontractors, or their employees, makes any warranty, express or implied, or assumes any legal liability or responsibility for the accuracy, completeness or usefulness of any information, apparatus, product or process disclosed, or represents that its use would not infringe privately owned rights.
DP-981

Nuclear Technology-Chemistry and Chemical Engineering $(\mathrm{M}-3679,43 \mathrm{rd} \mathrm{Ed}$.

This document consists of 20 Pages, Number 10 of $\underline{179}$ Coples, Series A .

\title{
PRECIPITATION OF PLUTONIUM(III) OXALATE AND CALCINATION TO PLUTONIUM DIOXIDE
}

by

John A. Porter and Albert E. Symonds, Jr.

Approved by

L. H. Meyer, Research Manager

Separations Chemistry Division

November 1965

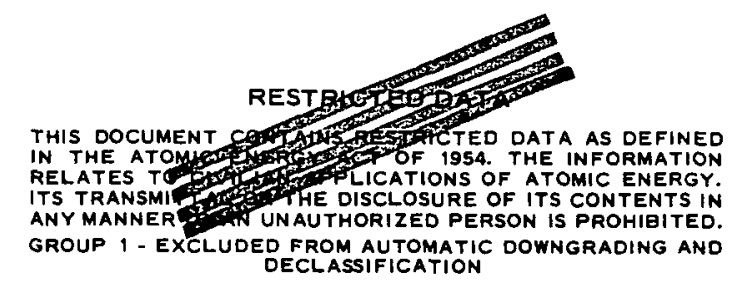

E. I. DU PONT DE NEMOURS \& COMPANY SAVANNAH RIVER LABORATORY

AIKEN, SOUTH CAROLINA

CONTRACT AT(07.2)-1 WITH THE

UNITED STATES ATOMIC ENERGY COMMISSION

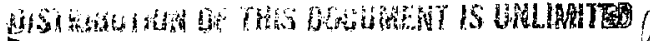




\section{DISCLAIMER}

This report was prepared as an account of work sponsored by an agency of the United States Government. Neither the United States Government nor any agency Thereof, nor any of their employees, makes any warranty, express or implied, or assumes any legal liability or responsibility for the accuracy, completeness, or usefulness of any information, apparatus, product, or process disclosed, or represents that its use would not infringe privately owned rights. Reference herein to any specific commercial product, process, or service by trade name, trademark, manufacturer, or otherwise does not necessarily constitute or imply its endorsement, recommendation, or favoring by the United States Government or any agency thereof. The views and opinions of authors expressed herein do not necessarily state or reflect those of the United States Government or any agency thereof. 


\section{DISCLAIMER}

Portions of this document may be illegible in electronic image products. Images are produced from the best available original document. 


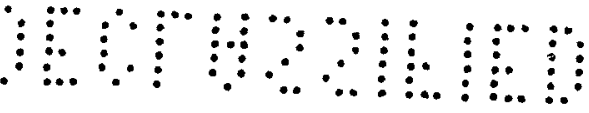

\section{IFIED}

\section{ABSTRACT}

Procedures were developed for the precipitation of plutonium(III) oxalate from nitric acid, hydrochloric acid, and sulfamic acid solutions. The plutonium was adjusted to $\mathrm{Pu}$ (III) with ascorbic acid in the presence of an oxidation Inhibitor. Plutonium dioxide was produced by calcining the oxalate in air at temperatures between 450 and $750^{\circ} \mathrm{C}$.

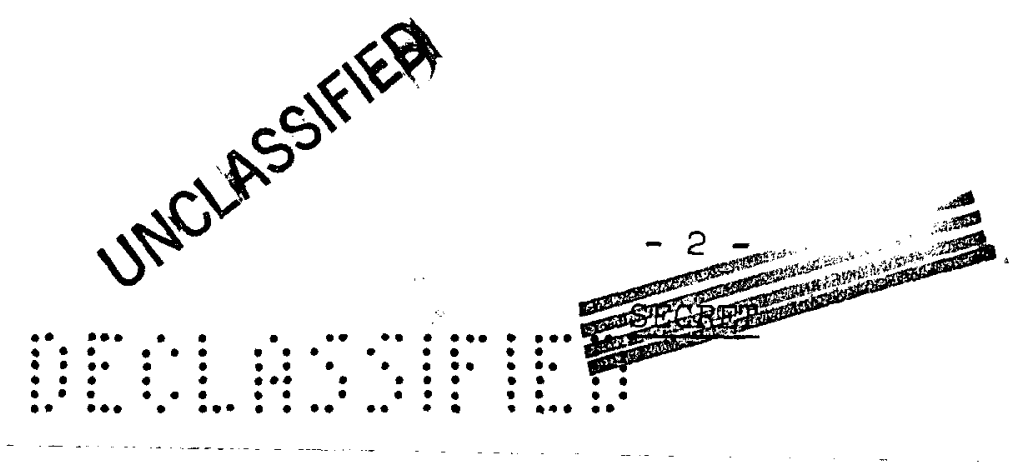




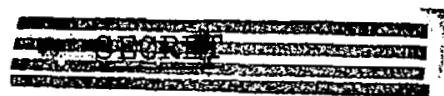

CONTENTS

Page

List of Tables and Figures . . . . . . . . . . . . . 4

INTRODUCTION . . . . . . . . . . . . . . . . . 5

SUMMARY . . . . . . . . . . . . . . . . 6

DISCUSSION . . . . . . . . . . . . . . . . . . . 7

Experimental Methods . . . . . . . . . . . . 7

Precipitation of Plutonium(III) Oxalate . . . . . . 8

Solubility Measurements . . . . . . . . . 8

Precipitation Procedure . . . . . . . . . . 10

Particle Size Distribution ............ 14

Radiolysis Effects ................ 15

Calcination of Plutonium(III) Oxalate to Plutonium Dioxide. . 16

BIBIIOGRAPHY . . . . . . . . . . . . . . . . . 19 


\section{LIST OF TABLES AND FIGURES}

$\underline{\text { Table }}$

Page

I Precipitation of Plutonium(III) Oxalate in Various Acid Medla . . . . . . . . . . . . . . . . 13

II Precipitation of ${ }^{238} \mathrm{Pu}$ (III) Oxalate.......... 15

\section{Figure}

I Effect of Nitric Acid and Oxalic Acid Concentrations on the Solubility of Plutonium(III) Oxalate . . . . . . 8

2 Effect of Hydrochloric Acid and Oxalic Acid Concentrations on the Solubility of Plutonium(III) oxalate. . . . . . . 9

3 Effect of Sulfamic Acid and Oxalic Acid Concentrations on the Solubility of Plutonium(III) Oxalate . . . . . . . 9

4 Particle Size Distribution of Plutonium Dioxide. . . . . 14 


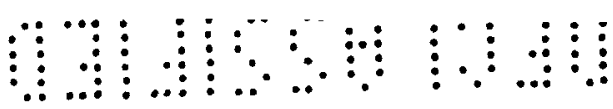

\title{
PRECIPITATION OF PLUTONIUM(III) OXALATE AND CALCINATION TO PLUTONIUM DIOXIDE
}

\author{
INTRODUCTION
}

The preparation of plutonium dioxide is often required in the processing of plutonium. The oxide is the desired final form for some applications, while for others oxide is an intermediate. Plutonium dioxide has been most often produced on a large scale by precipitation of plutonium(IV) peroxide or plutonium(IV) oxalate and subsequent calcination. The technology of these processes is well developed and is reported in the literature. $(1,2)$ The peroxide precipitation has the advantage of providing more extensive purification of plutonium from cationic impurities than does the oxalate precipitation. On the other hand, plutonfum(IV) oxalate is more easily filtered and handled than plutonium(IV) peroxide. In both precipitations, the solubility of the compounds is significant, and therefore, the loss of plutonium to the flitrates is relatively high; however, efficlent processes have been developed for partial recovery of the plutonium losses. The necessity for recovery operations is considered to be the greatest disadvantage of these processes.

Another method for producing plutonium dioxide is by precipitation of plutonium(III) oxalate and subsequent calcination. The preparation and properties of plutonium(III) oxalate are well-known and have been the subject of a number of investigations. $(2-\theta)$ Limited solubility data have been published. $(3,5,10)$ The thermal decomposition of the oxalate to the oxide has been thoroughly investigated by thermogravimetric techniques. $(8, \theta, 11)$ Although the literature indicates that the precipitation of plutonium(III) oxalate is a simple procedure, the preclpitation has seldom been used as a process step in the large-scale production of plutonium dioxide.

The neglect of plutonlum(III) oxalate for process use may have been due to the lack of suitable reducing agents to adjust the plutonlum to the $\mathrm{Pu}$ (III) state. Iodide ion has been employed successfully as a reductant prior to oxalate precipitation, $(\theta)$ but the corrosiveness of lodide toward stainless steel has limited 1ts use. Metal ions such as $\mathrm{Fe}^{2+}$ reduce plutonium to the $\mathrm{Pu}$ (III) state, but their use is undesirable because they form insoluble oxalates that precipitate with the plutonium. Hydroxylamine is a useful reagent for producing $\mathrm{Pu}$ (III) for oxalate precipitation ${ }^{(9)}$; however, the valence adjustment is slow and incomplete

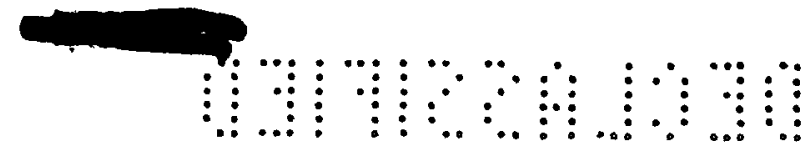


under some conditions. The development of ascorbic acid (or isoascorbic ac1d) as a reductant for producing $\mathrm{Pu}(\text { III })^{(12)}$ has provided a highly satisfactory reagent for use in the oxalate precipitation. Ascorbic acld rapidiy reduces plutonium to the $P$ (III) state in various acid media over a useful range of concentrations.

Perhaps the greatest potential advantage of the plutonium(III) oxalate precipitation is that the loss of plutonium to the filtrate is sufficiently low under proper conditions to eliminate the necessity of recovery operations. Also, the oxalate preclpitate is granular and easily filtered. The separation of plutonium from impurities is comparable to that obtained in the precipitation of plutonium(IV) oxalate.

The present investigation was undertaken to demonstrate the applicablitty and versatility of the plutonium(III) oxalate precipitation as a process route for plutonium dioxide production, and to develop the technical data and procedures necessary for plant applications.

\section{SUMMARY}

Procedures were developed for the precipitation of plutonium(III) oxalate from solutions of plutonium in nitric acid, hydrochloric acid, and sulfamic acid. In the preferred procedure, plutonium(III) oxalate is precipltated at room temperature by the slow addition of $1 \mathrm{M}$ oxalic acld to feed solutions contalning from $\sim 5$ to $>100 \mathrm{~g} / \mathrm{l}$ of plutonium in IM acid. Before precipitation, the plutonium is adjusted to Pu(III) by the addition of ascorbic acid in the presence of an oxidation inhibitor such as hydrazine or sulfamic acid.

Under the recommended conditions the loss of plutonlum to the filtrate is usually less than $20 \mathrm{mg} / \mathrm{l}$, and recovery operations are therefore not necessary. Solubility data for plutonium(III) oxalate in various acid solutions were determined to define optimum process conditions. The recommended preclpitation procedure yields plutonium(III) oxalate that is coarse, dense, and easily filtered. Small particle sizes can be produced when desired by simple modifications of the procedure.

Plutonium dioxide is produced by calcining alr-dried plutonium(III) oxalate in air at temperatures between 450 and $750^{\circ} \mathrm{C}$. The particle size distribution of oxide produced by calcination of the coarse oxalate precipitates is malnly in the 15 to 40 micron range, while oxide with a large percentage of particles in the 1 to $10 \mathrm{mlcron}$ range is produced from the finer precipitates. 


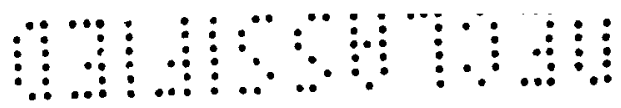

\section{DISCUSSION}

\section{EXPERIMENTAL METHODS}

Solutions of plutonium in various acid media were prepared for precipitation tests by standard techniques.

- Solutions of $\mathrm{Pu}$ (IV) in nitric acid were prepared by anion exchange. A solution containing $\sim \mathrm{g} \mathrm{Pu} / \mathrm{I}$ and $8 \mathrm{M}$ nitric acid was adjusted to $0.05 \mathrm{M}$ ferrous sulfamate and was heated briefly at $50^{\circ} \mathrm{C}$ to produce $\mathrm{Pu}(\mathrm{IV})$. The $\mathrm{Pu}(\mathrm{IV})$ was absorbed from this solution on a column of anion exchange resin, washed with $8 \mathrm{M}$ nitric acid, and eluted with $0.3 \mathrm{M}$ nitric ac1d.

- Solutions of $\mathrm{Pu}($ III) in nitric acid were prepared by cation exchange. A solution containing $\sim \mathrm{g} \mathrm{Pu} / \mathrm{l}$ and $0.3 \mathrm{M}$ nitric acid was adjusted to $0.05 \mathrm{M}$ hydroxylamine to produce $\mathrm{Pu}$ (III). The $\mathrm{Pu}$ (III) was absorbed from this solution on a column of cation exchange resin, washed with $0.3 \mathrm{M}$ nitric acid, and eluted with a solution containing $4.7 \mathrm{M}$ nitric acid and $0.3 \mathrm{M}$ sulfamic acid.

- Solutions of Pu(III) in hydrochloric acid or sulfamic acid were prepared by dissolution of plutonium metal in the respective acids.

The precipitation tests were performed in ordinary laboratory glassware scaled to accommodate from 1 to $100 \mathrm{~g}$ of plutonium. The precipitates were flitered by vacuum on medium-porosity fritted glass discs. The plutonium(III) oxalate was calcined to the dioxide in a tube-type furnace that was purged with air.

The equilibrium solubility of plutonium(III) oxalate in acid solutions was determined at room temperature. Pure plutonium(III) oxalate was equilibrated with solutions of known acid composition, and the solubility was determined at equilibrium. All plutonium analyses were by standard alpha counting techniques.

The particle size distribution of plutonium dioxide samples was determined by the Andreasen sedimentation technique. (13) With coarse oxlde samples, 50 wt $\%$ sulfurlc acld was used as the suspending medium; water served as the suspending medium for fine samples. With either medium, 0.05 wt $\%$ sodium pyrophosphate was added as a wetting agent. Plutonium analyses of the sedimentation fractions were performed by alpha counting techniques after dissolving the oxide samples in hot nitric acid solutions containing $0.05 \mathrm{M}$ potassium fluoride. 


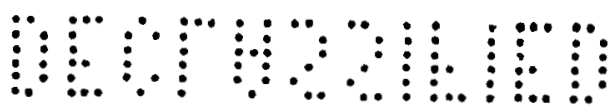



PRECIPITATION OF PLUTONIUM(III) OXALATE

\section{Solubility Measurements}

The solubility of plutonium(III) oxalate at room temperature as a function of various acld and oxalate concentrations was determined In order to establish the minimum plutonium loss attainable in the oxalate precipitation and to define the conditions for minimum loss. Solublilty data for nitric acid-oxalic acid solutions are shown in Figure 1; data for hydrochloric acid-oxalic acid and sulfamic acidoxalic acid solutions are shown in Figures 2 and 3 . These solutions all contained $0.05 \mathrm{M}$ ascorbic acid to stabilize the plutonium as Pu(III). The data show that the solubility of plutonium(III) oxalate increases rapidly with increasing nitric acid or hydrochloric acid concentration, but is less strongly influenced by sulfamic acid concentration. However, the maximum concentration of sulfamic acld attainable is only about $1.5 \mathrm{M}$ because of solubility limitations. The effect of increasing the oxalic acid concentration in nitric acid and hydrochloric acid solutions is to decrease the solubllity, but this trend appears to be reversed in sulfamic acid solutions.

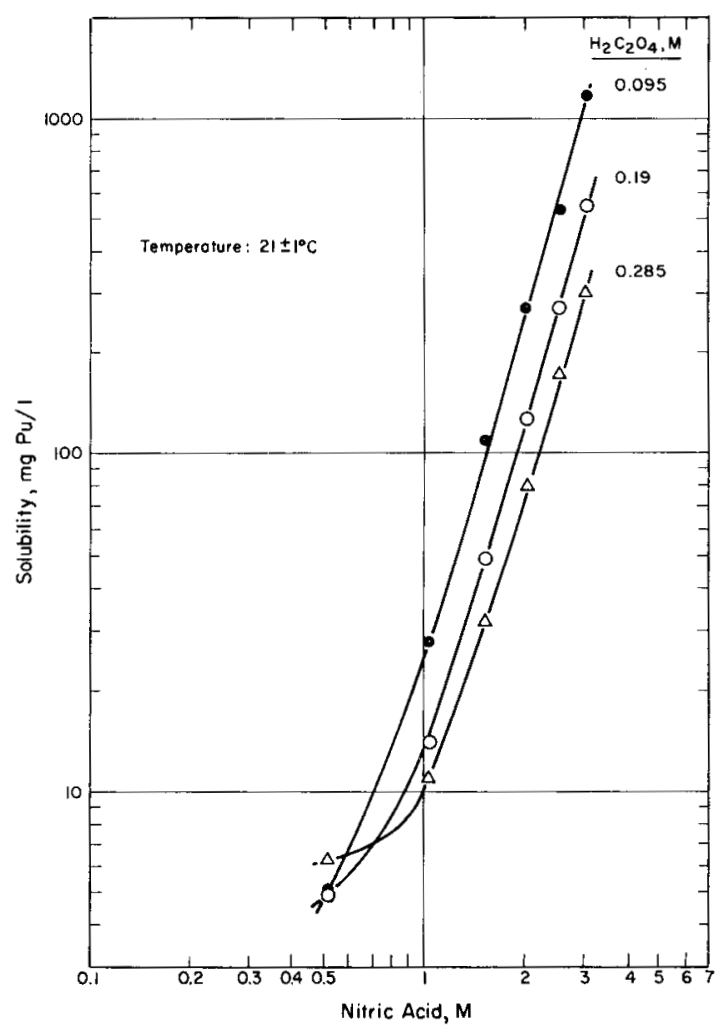

FIG. 1 EFFECT OF NITRIC ACID AND OXALIC ACID CONCENTRATIONS ON THE SOLUBILITY OF PLUTONIUM(III) OXALATE 

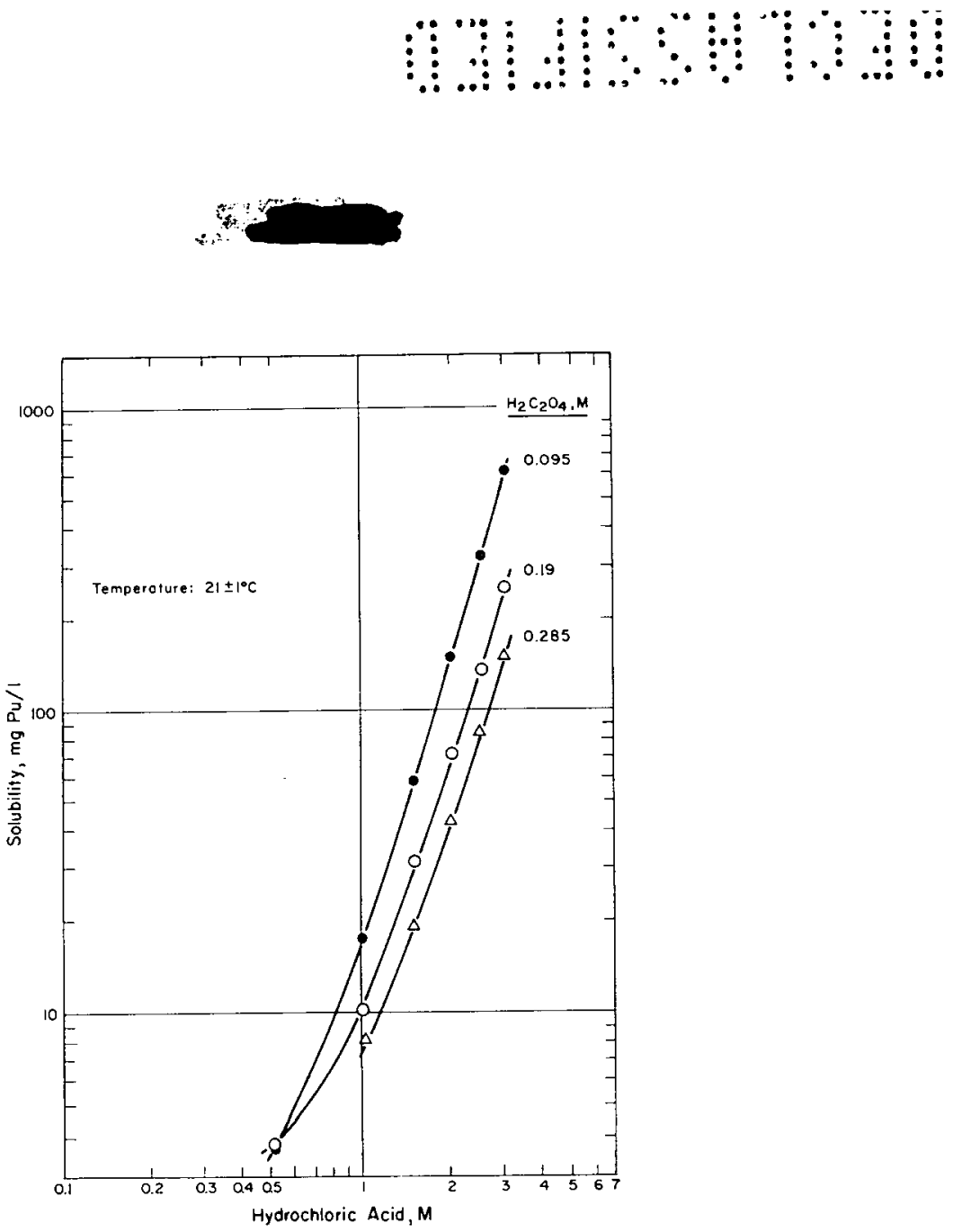

FIG. 2 EFFECT OF HYDROCHLORIC ACID AND OXALIC ACID CONCENTRATIONS ON THE SOLUBILITY OF PLUTONIUM(III) OXALATE

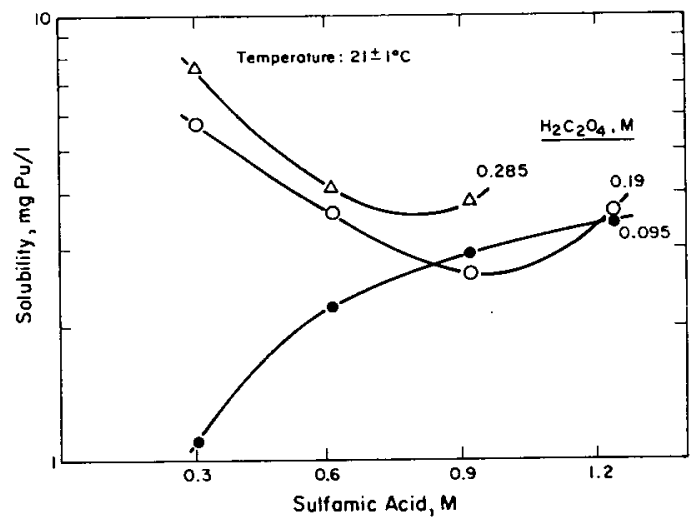

FIG. 3 EFFECT OF SULFAMIC ACID AND OXALIC ACID CONCENTRATIONS ON THE SOLUBILITY OF PLUTONIUM(III) OXALATE

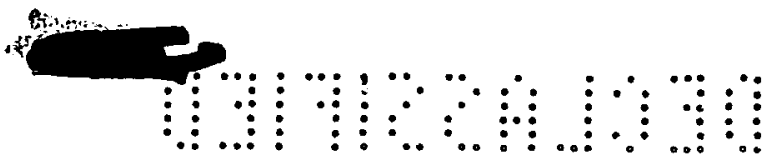




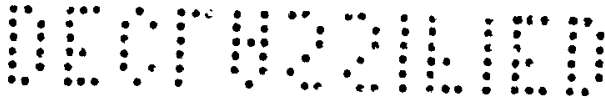

otom

The solubility data show that plutonium(III) oxalate should be precipitated from nitric acid or hydrochloric acld feed solutions at an acidity of IM, or lower, to minimize losses in the final slurry. Under these conditions, the recommended excess oxalic acid concentration is $\sim 0.2 \mathrm{M}$. Although this concentration of oxalic acid does not provide the lowest plutonium solubility, the volume of the filtrate is minimized (since the oxalic acld precipitant is added as IM solution), and the total plutonium loss is thus near the minimum. The solubility data Indicate that under these recommended conditions the loss of plutonium to the filtrate will be less than $20 \mathrm{mg} \mathrm{Pu} / 1$ if equilibrium is attalned.

The solubility data also show that plutonium(III) oxalate can be precipitated from sulfamic acld solutions with low plutonium loss without acld adjustment of most feed solutions. A $0.1 \mathrm{M}$ excess concentration of oxalic acid will minimize plutonium loss to the filtrate under most conditions. As the data show, the solubil1ty is less than $10 \mathrm{mg} \mathrm{Pu} / \mathrm{I}$ over a wide range of conditions. Thus, close control of acld and oxalate concentrations is not required when precipitations are from sulfamic acid solutions.

\section{Precipitation Procedure}

Plutonium(III) oxalate can be precipitated readily from nitric acid, hydrochloric acid, and sulfamic acid feed solutions containing from $\sim 5$ to $>100 \mathrm{~g} \mathrm{Pu} / 1$. The procedure is similar to that developed for precipitating neptunium(IV) oxalate(14). The main difference in the procedures is that the neptunium process is operated most satisfactorily at elevated temperature, while the plutonium process can be operated at room temperature. An operating temperature of about $50^{\circ} \mathrm{C}$ is required with neptunium to assure rapid reduction of the neptunium to the $\mathrm{Np}$ (IV) state with ascorbic acid, and to produce a dense, granular precipitate. Elevated temperature is not required with plutonium because reduction to $\mathrm{Pu}$ (III) with ascorbic acid is rapid, and coarse precipitates are obtained at room temperature. In plutonium(III) oxalate precipitations, as with neptunium, an oxidation inhibitor such as sulfamic acld or hydrazine is needed in the feed solution to scavenge oxidants (nitrite, radiolysis products) that could consume the ascorbic acid reductant and oxidize the $\mathrm{Pu}$ (III) to higher valence states.

The same general procedure (except for the feed adjustment) can be applied to precipitate plutonium(III) oxalate from nitric acid, hydrochloric acld, and sulfamic acid feed solutions. The general procedure is as follows:

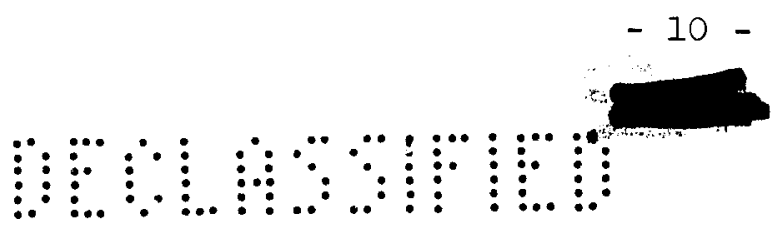




\section{आด}

- Feed Adjustment

Nitric Acid Solutions. Adjust the nitric acid concentration to less than 1.5M, preferably to $1 \mathrm{M}$ or lower. Adjust to $0.05 \mathrm{M}$ hydrazine or sulfamic acid and mix for 10 minutes.

Hydrochloric Acid Solutions. Adjust the hydrochloric acid concentration to less than $1.5 \mathrm{M}$, preferably to $1 \mathrm{M}$ or 10 wer. The use of an oxidation inhibitor is optional, but the addition of hydrazine or sulfamic acid to $0.05 \mathrm{M}$ may be beneficial.

Sulfamic Acid Solutions. No adjustment is required.

- Valence Adjustment

Add the amount of $1 \mathrm{M}$ ascorbic acid stoichiometrically required to reduce the plutonium to $\mathrm{Pu}$ (III) and provide a $0.03 \mathrm{M}$ excess. Mix for 10 minutes.

- Precipitation

Maintain efficient mixing. Add the stolchiometric amount of IM oxalic acid plus a $0.2 \mathrm{M}$ excess at a controlled rate over a period of 30 to 45 minutes. (A $0.1 M$ excess of oxalic acid is sufficient with sulfamic acid feed solutions.)

- Digestion

Agitate the slurry for 30 minutes.

- Filtration

Filter as rapidly as possible through a medium porosity frit.

- Washing

Wash the precipitate on the filter frit with about three cake volumes of 0.5 to $I M$ acid (nitric, hydrochloric, or sulfamic) containing $0.2 \mathrm{M}$ oxalic acid.

- Drying

Dry by aspiration of ambient air as required for subsequent processing. 


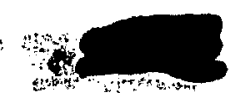

The above procedure yields a precipitate that is dense and granular and is easily filtered, washed, and dried. The filtration requires only 2 to $2-1 / 2$ times longer than the time required to filter an equal volume of water through the same filter under the same conditions. The precipitate dries to a free-flowing powder. The process is rather insensitive to most process variables except nitric acid or hydrochloric acid concentration. Under the recommended conditions, the loss of plutonium to the filtrate is usually less than $20 \mathrm{mg} / \mathrm{l}$; the wash losses are approximately the same. This small quantity of plutonium normally does not warrant recovery. Recovery, if required, could be accomplished easily by anion exchange processing after acid and valence adjustment of the waste solutions.

A problem that may be encountered under abnormal processing conditions is oxidation of the precipitated plutonium from $\mathrm{Pu}$ (III) to $\mathrm{Pu}$ (IV). This phenomenon is most likely to occur in nitric acid systems. Oxidation can occur in the precipitator if the precipitate is not maintained in the slurried state. Stagnant layers of precipitate oxidize within several hours, the time depending upon the temperature and the nature and concentration of oxidants present. Oxidation of slurried precipitates will not normally occur unless the slurried precipitates are held until the reductant is depleted, usually after several days. Oxidation in the precipitator is highly undesirable because the solubility loss of plutonium is increased, and the oxidized precipitates are difficult to filter. Oxidation of filtered precipitates may occur upon standing, particularly if incompletely dried. Fully dried precipitates are rather stable toward oxidation under normal conditions. Oxidation of filtered precipitates may or may not be objectionable, depending upon the subsequent processing required. Both plutonium(III) and plutonium(IV) oxalate are readily calcined to the dioxide.

Typical performance data are shown in Table $I$. 


\section{4⿻}



\section{TABLE I}

Preclpitation of Plutonium(III)

Oxalate in Various Ac1d Media $(a)$

Nitric Ac1d

\begin{tabular}{|c|c|c|c|}
\hline \multicolumn{2}{|c|}{ Feed Composition } & \multicolumn{2}{|c|}{ Pu Loss in Filtrate } \\
\hline $\mathrm{HNO}_{3}, \mathrm{M}$ & $\mathrm{g} \mathrm{Pu} / \mathrm{I}$ & $\mathrm{mg} \mathrm{Pu/l}$ & $\mathrm{Pu}$ \\
\hline 1.0 & $28.1^{(b)}$ & 24 & 0.13 \\
\hline 1.0 & $18.8^{(b)}$ & 20 & 0.16 \\
\hline 1.0 & $18.8^{(b)}$ & 12 & 0.09 \\
\hline 3.2 & $33.8^{(c)}$ & 100 & 0.46 \\
\hline 2.5 & $22.6^{(c)}$ & 45 & 0.30 \\
\hline 1.7 & $17.0^{(c)}$ & 21 & 0.18 \\
\hline
\end{tabular}

SuIfamic Acid

\begin{tabular}{|c|c|c|c|}
\hline \multicolumn{2}{|c|}{ Feed Composition } & \multicolumn{2}{|c|}{ Pu Loss in Filtrate } \\
\hline $\mathrm{NH}_{2} \mathrm{SO}_{3} \mathrm{H}_{2} \mathrm{M}$ & $\mathrm{gPu} / \mathrm{I}$ & $\mathrm{mg} \mathrm{Pu/1}$ & PPu \\
\hline 0.6 & 83.6 & 5 & 0.01 \\
\hline 0.5 & 94.0 & 6 & 0. \\
\hline & & 6 & \\
\hline
\end{tabular}

Hydrochloric Ac1d

\begin{tabular}{|c|c|c|c|}
\hline \multicolumn{2}{|c|}{ Feed Composition } & \multicolumn{2}{|c|}{$\mathrm{Pu}$ Loss in Filtrate } \\
\hline$\underline{\mathrm{HCl}}, \mathrm{M}$ & $\mathrm{g} \mathrm{Pu} / \mathrm{I}$ & $\mathrm{mg} \mathrm{Pu/1}$ & \% Pu \\
\hline 3.0 & 8.8 & 59 & 0.92 \\
\hline 1.2 & 3.4 & 10 & 0.40 \\
\hline 1.2 & 34.0 & 12 & 0.06 \\
\hline
\end{tabular}

(a) AII preclpitations were made with $0.2 \mathrm{M}$ excess oxalic acid. Approximately $0.03 \mathrm{M}$ excess ascorblc acid reductant was added to all feeds. Plutonium isotopic composition was mainly ${ }^{238} \mathrm{Pu}$.

(b) Plutonium feed solution was prepared by anlon exchange and contalned $0.05 \mathrm{M}$ sulfamic acid.

(c) Plutonium feed solution was prepared by cation exchange and contalned $0.3 \mathrm{M}$ sulfamic acid.






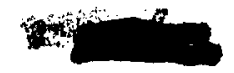

\section{Particle Size Distribution}

The particle size distribution of a typical sample of plutonium dioxide prepared by the recommended general precipitation procedure and subsequent calcination at $750^{\circ} \mathrm{C}$ is shown in Figure 4. As the data show, the oxide is composed mainly of particles between 15 and 40 microns in size. Plutonium dioxide of finer particle size may be required for some applications, and can be produced without difficulty by simple modifications in the plutonium(III) oxalate precipitation step. Three modifications that yield plutonium dioxide composed of a high percentage of particles in the 1 to 10 micron size range are described below.

Procedure A: Same as general procedure already described except that the IM oxalic acid preclpitant is added in $I$ minute rather than in 30 to 45 minutes.

Procedure B: Same as general procedure except that the plutonium feed solution is added to the IM oxalic acid precipitant.

Procedure C: Same as Procedure B except that 0.2M oxalic acid precipitant is used.

The particle size distributions of plutonium dioxide samples produced with these procedures are shown in Figure 4.

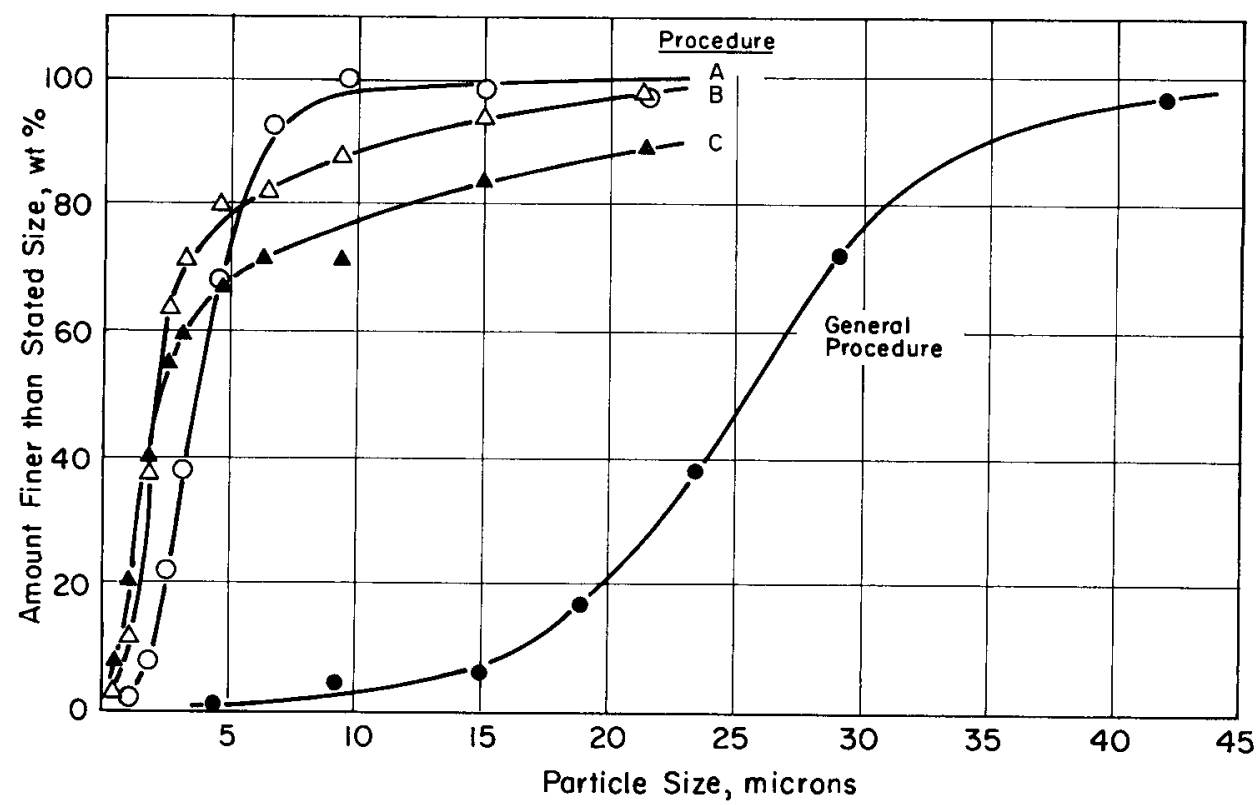

FIG. 4 PARTICLE SIZE DISTRIBUTION OF PLUTONIUM DIOXIDE 


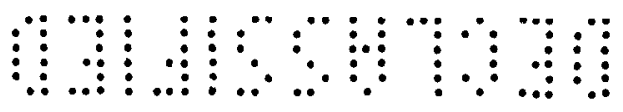

The above modiflcations give about the same loss of plutonium to the filtrate as does the general procedure. Because of the smaller particle size, however, the filtration time is increased by a factor of about three and the time required for complete drying is greatly increased. Occasional stirring of the filter cake will hasten drying and will prevent cake hardening. If the precipitate is not fully dried and powdered before calcination, the resulting oxide will contain many large agglomerates, which can however be subdivided easily by mechanical action.

\section{Radiolysis Effects}

The plutonium(III) oxalate precipltation was applied to varlous compositions of plutonium 1sotopes, 1ncluding plutonium that was pre-

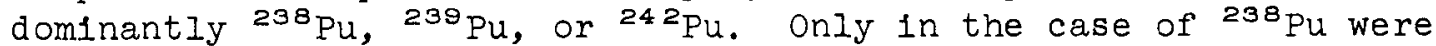
radiolysis effects troublesome. The specific alpha activity of ${ }^{238} \mathrm{Pu}$ is about 250 times that of ${ }^{239} \mathrm{Pu} .{ }^{238} \mathrm{Pu}$ is also a source of low-energy gamma radiation. The main effect of radiolysis in the precipitation is to oxidize $\mathrm{Pu}$ (III) to higher valence states and thus cause increased loss of plutonium to the flitrate and wash solutions. With the general precipitation procedure already described, the ${ }^{238} \mathrm{Pu}$ loss to the filtrate is 4 to 5 times that observed with ${ }^{239} \mathrm{Pu}$, and the loss to the wash solution is even higher. Increased concentrations of oxidation inhibitor and reductant in the feed solution, and the inclusion of these reagents In the wash solution decreases (but does not eliminate) the losses. Increasing the rate of flltration also decreases the losses; but even with these remedial procedures, the loss of ${ }^{238} \mathrm{Pu}$ is still 2 to 3 times that observed with ${ }^{239} \mathrm{Pu}$. The precipitation data in Table II demonstrate these effects.

\section{$\underline{T A B L E \text { II }}$}

Precipitation of ${ }^{238} \mathrm{Pu}$ (III) Oxalate

\begin{tabular}{|c|c|c|c|c|c|c|c|c|}
\hline \multirow[b]{2}{*}{ Run } & \multicolumn{4}{|c|}{ Feed Composition } & \multicolumn{2}{|c|}{ F1ltrate Loss (a) } & \multicolumn{2}{|c|}{ Wash Loss (b) } \\
\hline & $\mathrm{gPu} / \mathrm{I}(\mathrm{C})$ & $\mathrm{HNO}_{3}, \mathrm{M}$ & $\mathrm{N}_{2} \mathrm{H}_{4}, \quad \mathrm{M}$ & $\mathrm{C}_{Q} \mathrm{H}_{8} \mathrm{O}_{B}(\mathrm{~d}), \mathrm{M}$ & $\mathrm{mg} \mathrm{Pu} / \mathrm{I}$ & $\not{q}$ & $\mathrm{mg} \mathrm{Pu} / \mathrm{I}$ & 8 \\
\hline$I$ & 7.9 & 1.0 & 0.05 & 0.05 & 69 & 1.2 & 123 & 0.08 \\
\hline 2 & 7.9 & 1.0 & 0.1 & 0.1 & 54 & 1.0 & 126 & 0.08 \\
\hline 3 & 7.9 & 1.0 & 0.1 & 0.1 & 43 & 0.8 & 62 & 0.04 \\
\hline 4 & 10.0 & 1.4 & 0.1 & 0.1 & 41 & 0.6 & 45 & 0.02 \\
\hline 5 & 10.0 & 1.4 & 0.1 & 0.1 & 30 & 0.4 & 45 & 0.02 \\
\hline 6 & 10.0 & 1.4 & 0.1 & 0.1 & 32 & 0.6 & 59 & 0.03 \\
\hline
\end{tabular}

(a) Filtration times in Runs 4, 5, and 6 were 30 to $50 \%$ shorter than in other runs.

(b) Wash solution composition in Runs $\mathrm{I}$ and 2 was $1 \mathrm{M} \mathrm{HNO}_{3}-0.2 \mathrm{M} \mathrm{H}_{2} \mathrm{C}_{2} \mathrm{O}_{4}-0.05 \mathrm{M} \mathrm{N}_{2} \mathrm{H}_{4}$. In the remaining runs, $0.05 \mathrm{M}$ ascorbic acid was also present.

(c) Plutonium was approximateiy $80 \%{ }^{238} \mathrm{Pu}$.

(d) Ascorbic acid.
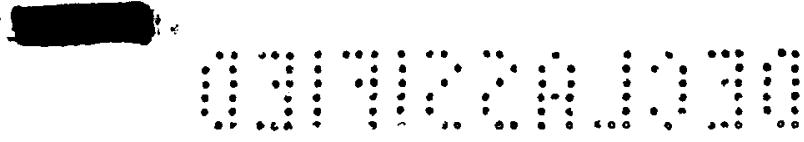

cake-the plutonium concentration of the supernatant solution in the precipitator corresponds to the expected solubility, while the concentration in the flltrate and wash solutions is much higher. Thus, rapid filtration and washing of the precipitate is desirable. Centrifugation would probably result in lower losses than filtration. Since the plutonium content of the filtrate and wash solutions is in excess of the equilibrium solubility of plutonium(III) oxalate, and since excess ascorbic acid reductant is present, reprecipitation of the excess plutonium in these solutions will occur within several hours. The precipitate can be recovered by subsequent refiltration of the solutions through a clean filter, with the result that the over-all loss of plutonium is not significantly greater than the expected solubility loss.

${ }^{238} \mathrm{Pu}$ (III) oxalate can be prepared and isolated, but it cannot be preserved because of radiolytic decomposition. During the first few hours after ${ }^{238} \mathrm{Pu}$ (III) oxalate is filtered, the color gradually changes from the original bright green to a darker green; within 24 hours, the color changes to a dark brown. The precipitate undergoes a loss in welght concurrently with the color changes and after several days the weight loss usually corresponds to almost complete conversion to plutonium dioxide. Intermediate products in the course of the radiolytic decomposition could not be identifled by $X$-ray diffraction analysis. Calcination at any stage of decomposition yields crystalline plutonium dioxide.

\section{CALCINATION OF PLUTONIUM(III) OXALATE TO PLUTONIUM DIOXIDE}

Thermogravimetric analyses $(8,9,11)$ of air-dried plutonium(III) oxalate have shown its composition to be $\mathrm{Pu}_{2}\left(\mathrm{C}_{2} \mathrm{O}_{4}\right)_{3} \cdot 1 \mathrm{OH}_{2} \mathrm{O}$. These analyses have also shown that when the compound is heated in air, decomposition occurs in several stages yielding intermediate products and eventualiy plutonium dioxide. Decomposition to plutonium dioxide is appreciable at $300^{\circ} \mathrm{C}$ and is almost complete at $400^{\circ} \mathrm{C}$. However, small additional welght losses will occur with continued heating to higher temperatures. For example, plutonium dioxide that has been calcined at $450^{\circ} \mathrm{C}$ will lose about $2 \%$ in weight upon heating to $800^{\circ} \mathrm{C}$.

Plutonium dioxide was prepared in these studies by the following procedure: Air-dried plutonium(III) oxalate was heated under a stream of air from room temperature to $125^{\circ} \mathrm{C}$ over a 1 -hour period and ma1ntained at this temperature for 1 hour. During this step most of the water of hydration evolved. The temperature was then increased at the rate of 3 to $5^{\circ} \mathrm{C}$ per minute to the desired final calcining temperature, and was maintained at that temperature for 1 to 2 hours. The product 


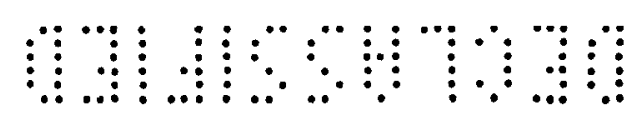

was cooled to room temperature under the air stream. The final calcination temperature ranged from 450 to $750^{\circ} \mathrm{C}$ depending on the intended use of the product.

The above procedure ylelds plutonlum dioxide that is olive to olive-brown in color and has a tapped density usually between 2.0 and $2.5 \mathrm{~g} / \mathrm{cc}$. Oxide produced from coarse particle plutonium(III) oxalate is free-flowing and relatively dust-free. Oxide from small particle size oxalate is less free-flowing and tends to dust somewhat, but handling is not particularly difficult. oxide produced by calcination within the specified temperature range is not refractory; it can be dissolved readily in hot concentrated nitric acid containing about $0.05 \mathrm{M}$ fluoride ion. 


\section{H HO ONCLASSIFIED}

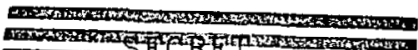



(1)

\section{BIBLIOGRAPHY}

1. E. W. Mainland, D. A. Orth, E. I. Field, and J. H. Radke.

"Production of Plutonium Metal." Ind. Eng. Chem. 53, 685 (1961).

2. J. F. Facer, Jr. and K. M. Harmon. Precipitation of Plutonium(IV) Oxalate. USAEC Report $\mathrm{HW}-31186$, General Electric Co., Hanford Atomic Products Operation, Richland, Wash. (1954) (Secret).

3. C. A. Thomas and J. C. Warner. The Chemistry, Purification, and Metallurgy of Plutonium. USAEC Report MUC-JCW-223, Book I, University of Chicago, Metallurgical Laboratory, Chicago, Ill. (1944).

4. D. F. Mastick and A. C. Wahl. Ultramicrochemical Investigations of the Solubilities of Some Plutonium Compounds. USAEC Report LADC-182, University of California, Los Alamos Scientific Laboratory, Los A.lamos, N. M. (1944).

5. E. S. Maxwell. Some Observations on the Basic Chemistry of Plutonium. USAEC Report IA-154, University of California, Los Alamos Scientific Laboratory, Los Alamos, N. M. (1944).

6. F. H. Pittman. Recovery and Purification of Plutonium. USAEC Report IA-14I, University of California, Los Alamos Scientific Laboratory, Los Alamos, N。M. (1944).

7. S. E. Bakes, J. Crom, C. S. Garner, I. B. Johns, and G. H. Moulton. Large-Scale Preparation of the Anhydrous FIuorides of Plutonium. USAEC Report IA-193, University of California, Los Alamos Scientific Laboratory, Los Alamos, N. M. (1944).

8. J.K. Dawson and R. M. Elliott. The Thermogravimetry of Some Plutonium Compounds. Report AERE-C/R-1207, Atomic Energy Research Establishment, Harwell, Berks, England, 20 p (1953).

9. G. S. Rao, M. S. Subramanian, and G. A. Welch. "Thermal Decomposition of Plutonium Oxalates." J. Inorg. Nucl. Chem. 25, 1293-5 $(1963)$.

10. J.S. Gritfo, W. B. Brown, and F. D. Lonadier. Solubility of Plutonium Compounds. USAEC Report MLM-1191, Monsanto Research Corporation, Mound Laboratory, Miamisburg, Ohio (1963).

11. R. E. Kartushova, T. I. Rudenko, and V. V. Fomin. "Thermal Decomposition of Quadrivalent and Trivalent Plutonium Oxalates." Soviet J.At. Energy 5, No. 1, 831-5 (1958) (English translation). 
UNCLASSIFIED

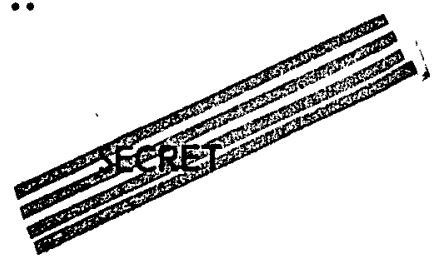

12. F. W. Toper and E. R. Russell. Concentration of Plutonium by Cation Exchange-Stabilization of Pu(III) in Nitric Acid. USAEC Report DP-349, E. I. du Point de Nemours and Co., Savannah River Laboratory, Aiken, S. C. (1959).

13. G. A. Loomis. "Grain Size of Whiteware Clays as Determined by the Andreasen Pipette." J. Amer. Ceram. Soc. 21, 393-9 (1938).

14. J. A. Porter. "Production of Neptunium Dioxide." Ind. Eng. Chem. Process Design and Development 3 , 289-92 (1964). 